\title{
Sweeteners and sweet taste enhancers in the food industry
}

\author{
Monique CARNIEL BELTRAMI ${ }^{1}$, Thiago DÖRING², Juliano DE DEA LINDNER ${ }^{3 *}$
}

\begin{abstract}
The search for new sweeteners technologies has increased substantially in the past decades as the number of diseases related to the excessive consumption of sugar became a public health concern. Low carbohydrates diets help to reduce ingested calories and to maintain a healthy weight. Most natural and synthetic high potency non-caloric sweeteners, known to date, show limitations in taste quality and are generally used in combination due to their complementary flavor characteristics and physicochemical properties in order to minimize undesirable features. The challenge of the food manufacturers is to develop low or calorie-free products without compromising the real taste of sugar expected by consumers. With the discovery of the genes coding for the sweet taste receptor in humans, entirely new flavor ingredients were identified, which are tasteless on their own, but potentially enhance the taste of sugar. These small molecules known as positive allosteric modulators (PAMs) could be more effective than other reported taste enhancers at reducing calories in consumer products. PAMs could represent a breakthrough in the field of flavor development after the increase in the knowledge of safety profile in combination with sucrose in humans.
\end{abstract}

Keywords: positive allosteric modulators; sweet taste receptor; sugar; non-caloric sweeteners.

Practical Application: The food industry uses more and more sweeteners to supply the demand for alternative sugar substitutes in products with no added, low or sugar free claims. Along with the interest in sugar reduction, there has also been a continuing industrial focus on clean label formulations, such as in the natural sweeteners added products. To increase this knowledge, the article presents detailed information concerning potency, technological properties and food applications of synthetic and natural sweeteners. Furthermore, this work discusses the challenges and possible application of sweet taste enhancers in the food industry.

\section{Introduction}

Since the end of the twentieth century, obesity has been one of the greatest public health concerns worldwide (Disse et al., 2010), with consequences beyond esthetic issues, as it is considered a risk factor for many different diseases (Fujiwara et al., 2012; Ribeiro \& Santos, 2013), such as cardiac conditions, hypertension and diabetes. To limit the prevalence of diseases related to the excessive consumption of sugar, researchers have worked on the isolation of naturally occurring compounds and development of synthetic sweeteners. These sweeteners are able to replace sugar totally or partially, but are rarely as satisfying as the full sugar alternative because they fail to trigger physiological satiety mechanisms (Raben et al., 2002; Swithers et al., 2010).

Unlike sucrose, most sweeteners exhibit undesirable off-tastes as concentration increases, shifting from pleasant (sweet) towards unpleasant (bitter/metallic) (Riera et al., 2007), and are also associated with severe side effects, including psychological problems, mental disorders, bladder cancer, heart failure and brain tumors (Kant, 2005; Sun et al., 2006). Some of the most commonly used non-caloric sweeteners include saccharin, aspartame, cyclamate, sucralose and acesulfame K (Butchko et al., 2001).
Due to the ongoing demand for alternative sugar substitutes, there has been a large research effort over the past several decades aimed at identifying the human genes coding for the sweet taste receptor. The use of high-throughput screening technologies and classical discovery approaches has enabled the discovery of novel sweeteners as well as sweet taste enhancers, known as positive allosteric modulators (PAMs), which are absolutely tasteless at the intended usage levels, but potentially enhance the activity of agonists of the sweet taste receptors and, therefore, sweetness perception.

Innova Market Insights published that over 16\% of global soft drinks launched in the 2016 used either no added sugar, low sugar or sugar free claims. Along with the interest in sugar reduction, there has also been a continuing focus on clean label formulations, such as stevia and monk fruit. Soft drinks accounted for $20 \%$ of recent launches featuring stevia (Gelski, 2016).

This review will discuss the current knowledge on the existing alternatives for sugar replacement and studies that are being done towards the identification of substances with enhancement 
properties. Here, we also describe the advantages and possible applications of sweet taste enhancers in the food industry.

\section{Sweet taste receptor}

To evaluate the quality of food components, sensory information of taste is needed. In general, humans can detect at least five basic taste qualities: sweet, salty, umami, sour and bitter (Meyers \& Brewer, 2008). The mechanism of detection of these taste qualities begins with the taste receptor on the apical membrane of taste receptor cells in the tongue. These receptors bind to taste substances, recognizing them and activate the taste cells which then transmit sensory information to nerve cells and into the brain (Strapasson et al., 2011).

Physiologically, sweet, bitter and umami tastes are mediated by G protein-coupled receptors (GPCRs), called type 1 taste receptors (T1Rs) for sweet and umami and type 2 taste receptors (T2Rs) for bitter taste. Type 1 taste receptor 3 (T1R3) subunit combines with type 1 taste receptor 2 (T1R2) subunit to form a sweet taste receptor, which is expressed in the oral cavity, where it provides input on the caloric and macronutrient contents of ingested food. This receptor recognizes all the compounds (natural or artificial) perceived as sweet by people (Belloir et al., 2017). Each of these has a section characterized by a large extracellular venus flytrap domain (VFT), which is stabilized in the closed conformation when a sweetener binds. Apparently, the sweet taste enhancers are most likely to bind to T1R2 subunit adjacent to the flytrap opening, linked to a transmembrane domain (TDM) via a short cysteine-rich domain (CRD), helping it to stay closed once the sweetener has struck (Nelson et al., 2001; Zhao et al., 2003).

\section{Alternatives to sugar}

Early in the 20th century, scientists have identified many synthetic and natural sweet-tasting compounds. Most of these compounds consist of substances with a very intense sweet taste that are used in small amounts to replace the sweetness of a much larger amount of sugar (Gardner et al., 2012) and are referred to as high potency (HP) sweeteners. Sweeteners are chemically diverse including natural sugars, sugar alcohols, natural and synthetic sweeteners, and sweet-tasting proteins. These substances have a continuous great interest as they assist the food industry in developing good-tasting reduced calorie products to meet the consumers' and health professionals' expectations (Klug \& Lipinski, 2011).

The number of approved substances has increased substantially in the past three decades, allowing food developers to choose from a variety of sweeteners, as they differ from each other not only in potency, but also in mouthfeel, duration of sweetness, aftertaste, solubility and stability. These current alternatives to sugar enable manufacturers to use an ingredient or a combination of ingredients best suited for a given product, since no sweetener is perfect for all uses (Nabors, 2011).

Synthetic or naturally occurring sucrose substitutes are required to exhibit a sucrose-like taste quality with properties such as demonstrated non-toxicity, non-cariogenic and no effects on blood glucose or insulin. Studies suggest that sweetness, when not accompanied by calories, might result in ambiguous psychobiological signals that confuses the body's regulatory mechanisms, leading to a loss of control over appetite and overeating (Bellisle \& Drewnowski, 2007).

The usage of sweeteners in food and beverages is regulated according to the accepted daily intake (ADI) values, which define the estimated amount of a determined substance that a person can consume on average every day without risk, assigned by regulatory agencies following review of safety assessment studies (Kroger et al., 2006).

The Unites States Food and Drug Administration published in 2015 an issue regarding additional information about high-intensity sweeteners permitted for use in food in the United States. Saccharin, aspartame, acesulfame potassium, sucralose, neotame, advantame, steviol glycosides and Luo Han Guo fruit extracts were reviewed regarding approved use and safety for human consumption. For example, sucralose has been extensively studied and more than 110 safety studies were reviewed by FDA in approving the use as a general purpose sweetener for food (U.S. Food and Drug Administration, 2015).

\subsection{Synthetic sweeteners}

Many synthetic compounds were identified serendipitously without the understanding of the mechanism for sweetness in a time when taste and smell were key dimensions for evaluation, and this routine testing continued into the $20^{\text {th }}$ century. With the development of chromatography and spectroscopy methods, human routine sensory assessment of compounds was gradually discontinued. Nevertheless, the unintentional discovery of many sweet taste compounds continued in the years to follow (Schiffmann \& Gatlin, 1993; Davies, 2010).

The majority of the currently available sweeteners in the world market are synthetic compounds, but their use depends on the granting of legislative approval, for which individual countries have their own regulatory requirements (Grenby, 1991; U.S. Food and Drug Administration, 2015). Despite the considerable market value of synthetic sweeteners, problems have been perceived with some of these compounds in terms of their safety, stability, cost, and/or quality of taste. As shown in Table 1, ten synthetic non-caloric sweeteners were discussed by diverse authors in terms of potency, technological properties and beverage and food applications.

\subsection{Natural sweeteners}

In recent years, as the incidence of overweight and diabetic people has increased worldwide, there has been a great demand for new alternative low or no-calorie sweeteners for dietetic and diabetic purposes (Kim \& Kinghorn, 2002; Freitas et al., 2014). There are many artificial sweeteners, but their use is limited because they are often associated with harmful side effects (Tandel, 2011). As a consequence, the search for sugar substitutes of natural sources has led to the discovery of a number of substances that possess an intensely sweet taste or taste-modifying properties. Over a hundred plant materials have been found to taste sweet because they contain large amounts of sugars and/or polyols or other sweet constituents. Although these sweeteners may 
Table 1. Potency, technological properties and beverage and food applications of synthetic sweeteners.

\begin{tabular}{|c|c|c|c|}
\hline Sweetener & Potency* & Technological properties & Beverage and food applications \\
\hline Acesulfame-K & $100-200(1,3,8)$ & $\begin{array}{l}\text { Good water solubility; very stable in solid forms, } \\
\text { sweetness synergy in blends with improved taste profile; } \\
\text { bitter and metallic off-tastes in high concentrations ( } 3 \text {; } \\
\text { not decomposed with digestion (9). }\end{array}$ & $\begin{array}{l}\text { Carbonated and uncarbonated beverages }(3,5) \text {, } \\
\text { confectionery, baked goods, fruit-flavored dairy } \\
\text { products, delicatessen products and tabletop } \\
\text { preparations (6). }\end{array}$ \\
\hline Advantame & $\begin{array}{l}20,000-40,000 \\
\quad(3,8)\end{array}$ & $\begin{array}{l}\text { Very stable in the solid form; } \mathrm{pH} \text { dependent stability } \\
\text { in solution; clean sweetness without off-tastes; slow } \\
\text { sweetness onset and sweetness linger (3). }\end{array}$ & As an artificial flavor (3). \\
\hline Alitame & $2,000(5,8,9)$ & $\begin{array}{l}\text { Very stable to } \mathrm{pH} \text { and temperature variation }(9,10) \text {; } \\
\text { non-cariogenic }(10) \text { clean, sweet taste with no metallic } \\
\text { bitter notes; sweet taste that lingers }(9) \text {. }\end{array}$ & $\begin{array}{l}\text { Food (e.g. baked goods) }(5,8,9) \text { and beverages } \\
\text { (e.g. carbonated) (9) and as a sweetener }(5) \text {. }\end{array}$ \\
\hline Aspartame & $100-200(1,3,8)$ & $\begin{array}{l}\text { Stable in its crystalline form; clean sweet taste without } \\
\text { off-tastes; enhances citrus flavors; unstable in neutral pH } \\
\text { and at high temperatures }(3,5,9) \text {; moderate sweetness } \\
\text { linger }(3,9) \text {; degraded into phenylalanine }(3,7,10) \text {. }\end{array}$ & $\begin{array}{l}\text { Sweetener, blends, carbonated and uncarbonated } \\
\text { beverages }(3,5) \text {, yogurt, confectionery }(2) \text { and } \\
\text { pasteurized and sterilized flavored milk ( } 7) \text {. }\end{array}$ \\
\hline Cyclamate & $\sim 30(1,3,8)$ & $\begin{array}{l}\text { Very stable in the solid form }(3,5,9) \text {; weak bitter and salty } \\
\text { tastes; no significant off-tastes; fast sweetener onset with } \\
\text { no sweetness linger (3), enhances fruity flavors (9). }\end{array}$ & $\begin{array}{l}\text { Sweetener blends, food (e.g. baked goods, } \\
\text { confectionery) }(3) \text { and beverages }(3,5) \text {. }\end{array}$ \\
\hline $\begin{array}{l}\text { Neohesperidin } \\
\text { dihydrochalchone }\end{array}$ & $\begin{array}{c}250-2,000 \\
(3,8,10)\end{array}$ & $\begin{array}{l}\text { Very stable in solution and } \mathrm{pH} \text { variation }(3,4) \text {; bitter, } \\
\text { cooling and licorice like off-tastes; slow sweetness onset } \\
\text { and long lingering taste }(3) \text {. }\end{array}$ & $\begin{array}{l}\text { Sweeteners blends, artificial flavor ( } 3 \text { ) and flavor } \\
\text { modifier (5). }\end{array}$ \\
\hline Neotame & $\begin{array}{l}7,000-13,000 \\
(1,3,8)\end{array}$ & $\begin{array}{l}\text { Very stable in the solid form; clean sweetness with no off- } \\
\text { tastes; strong sweetness linger ( } 3 \text { ). }\end{array}$ & $\begin{array}{l}\text { Sweetener, sweetener blends ( } 3 \text { ), food and } \\
\text { beverages (5). }\end{array}$ \\
\hline Saccharin & $300-500(1,3,8)$ & $\begin{array}{l}\text { Very stable in the solid form and in solution (3); bitter } \\
\text { and metallic off-tastes, fast sweetness onset without } \\
\text { significant lingering }(3,9) \text {. }\end{array}$ & $\begin{array}{l}\text { Sweetener blends, food (e.g. cooking) and } \\
\text { beverages ( } 3 \text { ). }\end{array}$ \\
\hline Sucralose & $\sim 600(1,3,8)$ & $\begin{array}{l}\text { Freely soluble in water; stable in solution; unstable at high } \\
\text { temperatures }(3,4,9) \text {; no bitter aftertaste }(4,9) \text {; sweetness } \\
\text { with a slight delay in onset with moderate linger }(3) \text {. }\end{array}$ & $\begin{array}{l}\text { Sweetener, blends, food (e.g. cooking and baking), } \\
\text { beverages (5) and as an artificial flavor ( } 3 \text { ). }\end{array}$ \\
\hline
\end{tabular}

${ }^{\star}$ Potency is expressed as times sweeter than sucrose. (1) Bellisle \& Drewnowski (2007); (2) Butchko et al. (2001); (3) DuBois \& Prakash (2012); (4) Grenby (1991); (5) Kroger et al. (2006); (6) Klug \& Lipinski (2011); (7) Kumari et al. (2016); (8) Nabors (2011); (9) Nelson et al. (2001); (10) Sardesai \& Waldshan (1991).

have some caloric value, their contribution to energy intake is negligible in the amounts used (Sardesai \& Waldshan, 1991; Bellisle \& Drewnowski, 2007).

Several of these highly sweet natural products have either been commercialized as sweeteners or flavoring agents in some countries as pure compounds, compound mixtures and refined extracts or are under development. The potency, technological properties and beverage and food applications of 12 natural sweeteners were discussed by diverse authors and are summarized in Table 2.

\section{Sweetness modulators}

Non-caloric HP sweeteners are generally limited in taste quality (Riera et al., 2007; Li et al., 2011) by many negative attributes, such as off-tastes, delay in sweetness onset, low maximal sweetness response, lingering aftertaste and sweet tastes that desensitize the gustatory system. Researchers have studied ways of combining non-caloric substances with one another or with carbohydrate sweeteners with different properties in order to obtain a complimentary taste profile that could reproduce the taste of sugar to its best (Priya et al., 2011). However, they noted that only minimal sweet taste enhancement could be achieved with such blends and apparent synergy in taste tests could only be observed at lower sweetener levels. Even though sweeteners, in general, show small enhancement effects, blends and new sweetener formulations remain very popular among the food and beverage industries.

Over the past years, numerous substances have been studied and categorized due to their sweet (Stoger, 2012), antisweet (Jyotaki et al., 2010; Sigoillot et al., 2012) and sweet-inducing abilities to enhance sweetness (Soldo et al., 2004; Hofmann, 2005; Yoshida et al., 2010) and modify or mask undesirable tastes (Gibbs et al., 1996; Nakajima et al., 2006). They played an important role on the elucidation of the structure and physiological activity of taste-modulating compounds (Soldo et al., 2003).

Recently, by the use of screening technologies and classical discovery approaches, researchers were able to identify completely new flavor ingredients, such as PAMs. These molecules are enhancers, which possess no taste on their own, but potentiate the taste of sugar (Ottinger \& Hofmann, 2003; Ottinger et al., 2003; Davies, 2010).

\section{Sweetener receptor positive allosteric modulators}

Studies involving chimeric receptors, mutagenesis and molecular modeling have revealed that the GPCRs are very susceptible to allosteric modulation. By screening synthetic chemical libraries, PAMs have been identified for several members of the metabotropic glutamate receptor and $\mathrm{GABA}_{\mathrm{B}}$ receptor (Koizumi et al., 2011). Every synthetic PAM identified for these receptors binds to the TDM to enhance activity and sometimes 
Table 2. Potency, technological properties and beverage and food applications of natural sweeteners.

\begin{tabular}{|c|c|c|c|}
\hline Sweetener & Potency $^{\star}$ & Technologial properties & Beverage and food applications \\
\hline Brazzein & $500-2,000(1,4,8)$ & $\begin{array}{l}\text { Stable to heat } \mathrm{pH} \text { variation }(1,4) \text {; sweetness with slow onset that } \\
\text { lingers (1). }\end{array}$ & Low calorie sweetener (4). \\
\hline Curculin & $550-9,000(2,6,8)$ & $\begin{array}{l}\text { Stable to heat and } \mathrm{pH} \text { variation }(4) \text {; sweet taste and sweet } \\
\text { modifying abilities }(4,8) \text { by eliciting a sweet taste response to } \\
\text { acids }(6) \text {. }\end{array}$ & Low calorie sweetener (4). \\
\hline Erythritol & $0.6-0.7(1,8)$ & $\begin{array}{l}\text { Stable to light and temperature (1); clean taste similar to sugar } \\
(1,6,8) \text {; cooling effect when tasted in solids (1); improves taste } \\
\text { profile when blended with HP sweeteners (1). }\end{array}$ & $\begin{array}{l}\text { Blends and bulk sweetener for cooking, } \\
\text { confectionery }(1) \text { and beverages }(1,8) \text {. }\end{array}$ \\
\hline Mabinlin & $100-400(2,4,8)$ & Heat stable (4). & 1 \\
\hline Miraculin & $400,000(6,8)$ & $\begin{array}{l}\text { Stable to } \mathrm{pH} \text { variation }(2) \text {; modifies sour taste into sweet }(4,6,8) \text {; } \\
\text { similar taste to sucrose }(9) \text {. }\end{array}$ & $\begin{array}{l}\text { Compressed freeze dried tablets ( } 8) \text { and } \\
\text { sour beverages }(9) \text {. }\end{array}$ \\
\hline Monatin & $2,700(1)$ & $\begin{array}{l}\text { Water soluble; clean sweet taste disadvantaged by a slow onset on } \\
\text { sweetness and sweet lingering aftertaste; unstable under sunlight } \\
\text { (1). }\end{array}$ & 1 \\
\hline Monellin & $2,500-3,000(8,10)$ & $\begin{array}{l}\text { Limited stability to } \mathrm{pH} \text { variation and temperature }(3,8) \text {; limited } \\
\text { taste properties (3). }\end{array}$ & 1 \\
\hline Pentadin & $\sim 500(4,6,8)$ & Slow onset and fast decline of sweetness (2). & 1 \\
\hline $\begin{array}{l}\text { Steviol } \\
\text { glycosides, } \\
\text { stevioside and } \\
\text { rebaudioside A }\end{array}$ & $200-400(1,8)$ & $\begin{array}{l}\text { Stable to heat (5); reduce tooth decay (10); bitter and licorice-like } \\
\text { aftertaste }(1,8) \text {. }\end{array}$ & $\begin{array}{l}\text { Blends with caloric and non-caloric } \\
\text { sweeteners, beverages }(1,8) \text { and foods } \\
\text { (e.g. picked vegetables, seafood) ( } 7 \text { ), } \\
\text { fruit drinks (5), chewing gums and dairy } \\
\text { products (8). }\end{array}$ \\
\hline
\end{tabular}

increases affinity of the natural ligand (glutamate, aminobutyric acid or calcium) within the VFT. While sweeteners bind near the hinge region to trigger the initial closure of the VFT, enhancers bind near the opening of the pocket and stabilize the closed conformation by strengthening the hydrophobic interactions between the two lobes and lowering entropic penalties of lobe closure. Upon binding to the receptors, PAMs exhibit little or no intrinsic agonist activity on their own or act both as agonists on their own and as enhancers for the endogenous agonists.

In order to improve the taste of HP sweeteners, PAMs may bind to the sweetener receptor without activating it, but do so in a manner that they cause carbohydrate sweeteners such as sucrose, fructose and glucose to bind with higher affinity. These molecules would be enhancers, or PAMs of the sweetener receptor. As they possess no sweetness activity, formulations associating carbohydrate sweeteners with PAMs should accurately replicate carbohydrate sweetener taste (Servant et al., 2011; DuBois \& Prakash, 2012).

The first examples of PAMs for the sweet taste receptor were identified at the company Senomyx Incorporation (San Diego, CA, USA) in 2007. One of these molecules, SE-2 was able to significantly enhance the activity and the potency of sucralose in a cell-based assay, but was not sweet on its own on the intended usage level and had no activity in the absence of sucralose (Gray, 2014).

Tested in a solution, it showed a reduction of four to six folds in the amounts of sugar, while maintaining the sweetness intensity. Further studies have identified other potent PAMs, SE-3 and SE-4, displaying an altered specificity, which allowed a reduction up to $50 \%$ in the amount of sugar, preserving the sweetness intensity. It was also identified that SE- 2 could be used to reduce the off-tastes related to high levels of sucralose in some products, and neither SE- 2 or SE- 4 were found to impart any bitterness, metallic taste or other temporal effects, allowing its use on different products which could taste identically to the fully sweetened equivalent (Zhang et al., 2010).

DuBois \& Prakash (2012) reviewed more examples of PAMs that have been claimed to enhance the sweetness intensities of common carbohydrate sweeteners: 2,4 dihydroxybenzoic acid (DHB), 4-amino-5,6-dimethylthieno(2,3-D)pyrimidin2(1H)-one (ADTP) and 3-[(4-amino-2, 2-dioxido-1H-2,1,3benzothiadiazin-5-yl)oxy]-2,2-dimethyl-N-propylpropanamide 
(ADBT). The work reviewed also other targeted at T1R2/ T1R3 PAMs, as for example: 3-Hydroxybenzoic acid (3HB) and especially mixtures of $3 \mathrm{HB}$ with $\mathrm{DHB}$ was reported to enhance the sweetness of sucrose as well as other commom carbohydrate sweeteners and some HP sweeteners (Bingley et al., 2007); 2-methoxy-5-(phenoxymethyl)-phenol at $5 \mathrm{mg} / \mathrm{L}$ was reported to cause a 1.3-fold sweetness enhancement effect (Flamme \& Bom, 2011); 3'-7-dihydroxy-4'-methoxyflavan was reported to enhance sucrose (1.6-fold) (Wessjohann et al., 2010).

\subsection{Industrial applications and challenges}

The definition of flavor enhancer is laid down in point 14 of Annex I of Regulation (EC) No 1333/2008 on food additives: "[...] flavor enhancers are substances which enhance the existing taste and/or odor of a foodstuff [...]" (European Flavour Association, 2015). According to the European Commission's Directorate General for Health and Consumers Guidance notes on the classification of flavoring substances with modifying properties and a flavor enhancer: "Substances that mainly enhance sweetness of food through intensifying the taste of added sugars or sweeteners should be considered as flavor enhancers. The intended function of the added substance is to enhance sweet flavor, thus leading to the possibility of reducing the amount of added sweet ingredients. The same approach would apply if the substance is added mainly to enhance the saltiness or sourness of food [...]" (European Union, 2014).

PAMs were approved by the Flavor and Extract Manufacturers Association (FEMA) as flavoring substances that have been described to be used in food and beverage applications, such as soft drinks and powdered beverages (Watson, 2014). It is apparent that the sweetener PAM technology is an exciting approach to calorie reduction of products with a taste quality which is not possible with HP sweeteners, but the results achieved so far are quite modest. It remains to be demonstrated that compounds exhibiting both agonist and enhancement properties are responsible for increasing effects, and not only additive sweetness (DuBois \& Prakash, 2012). However, PAMs do not have minimal toxicology data published by, for example, EFSA or WHO. Safety human tests of PAMs in combination with sucrose has not been adequately performed.

Other challenges in the field of PAMs include: identification of more efficacious PAMs that could enhance the taste of sugar to 20 -fold in order to cut beverage calories and enable the labeling of zero-calorie discovery of different enhancers for each sweetener, increasing specificity and therefore efficacy (Servant et al., 2010, 2011); isolation of PAMs with a broader spectrum of activity that are able to improve taste qualities of synthetic and natural HP sweeteners; identification of PAMs from natural origin with strong enhancement effects that are cost-effective because of the consumers' search for natural ingredients (Scott-Thomas, 2014).

\section{Conclusions}

Led by the increasing consumer desire for reduced calorie products with a more realistic sugar taste, the search for low or no-calorie sweeteners will continue. In recent years, although consumers have shown considerable interest for natural sweeteners as part of a growing trend for healthful products lacking of synthetic ingredients, compromise on taste quality is unlikely. In addition, some of the plant-derived substances are difficult to be isolated and many of them do not grow outside their natural environment, compromising their stability and being costly to produce.

With the discovery of human genes coding for the sweet taste receptor, the identification of novel synthetic and natural HP sweeteners is possible. However, the compounds identified and developed until now fail to mimic the taste of sugar. So far, sweetness enhancement has been reported for sweeteners combinations apparently showing modest synergistic effects and remains very popular in the industry. Nonetheless, measuring the effect of these combinations is difficult, since each of the components present inherent physicochemical properties and flavor characteristics that might be complementary.

In contrast, PAMs are not agonists and do not taste sweet on their own, simplifying the interpretation of the enhancement properties. They are able to enhance sweetness using a low concentration of modulator in a cost-effective manner, maintaining the real taste of sugar without any increase in caloric value. Therefore, the continuous search towards identifying additional selective enhancers for other commercially relevant sweeteners acting within the VFT of the sweet taste receptor could revolutionize the field of flavor development and sweetened products.

\section{References}

Bellisle, F., \& Drewnowski, A. (2007). Intense sweeteners, energy intake and the control of body weight. European Journal of Clinical Nutrition, 61(6), 691-700. http://dx.doi.org/10.1038/sj.ejcn.1602649. PMid:17299484.

Belloir, C., Neiers, F., \& Briand, L. (2017). Sweeteners and sweetness enhancers. Current Opinion in Clinical Nutrition and Metabolic Care, 20(4), 279-285. http://dx.doi.org/10.1097/MCO.0000000000000377. PMid:28399012.

Bingley, C. A., Olcese, G., \& Darnell, K. C. (2007). U.S. Patent No. 2007/0054023 A1. Washington, DC: U.S. Patent and Trademark Office.

Butchko, H. H., et al. (2001). Aspartame. In L. O. Nabors (Ed.), Alternative sweeteners (pp. 41-48). New York: Marcel Dekker.

Davies, E. (2010). Sweets for my sweet (pp. 46-89). London: Chemistry World.

Disse, E., Bussier, A. L., Veyrat-Durebex, C., Deblon, N., Pfluger, P. T., Tschöp, M. H., Laville, M., \& Rohner-Jeanrenaud, F. (2010). Peripheral ghrelin enhances sweet taste food consumption and preference, regardless of its caloric content. Physiology \& Behavior, 101(2), 277-281. http://dx.doi.org/10.1016/j.physbeh.2010.05.017. PMid:20515700.

DuBois, G. E., \& Prakash, I. (2012). Non-caloric sweeteners, sweeteners modulators and sweetener enhancers. Annual Review of Food Science and Technology, 3(1), 353-380. http://dx.doi.org/10.1146/annurevfood-022811-101236. PMid:22224551.

European Flavour Association - EFFA. (2015). Guidance Document on the EC Regulation on Flavourings. Retrieved from http://www. effa.eu/docs/default-source/guidance-documents/effa_guidancedocument-on-the-ec-regulation-on-flavourings.pdf?sfvrsn $=2$

European Union. (2014). European Commission's Directorate General Health and Consumers. Guidance notes on the classification of a 
flavouring substance with modifying properties and a flavor enhancer. Retrieved from http://ec.europa.eu/food/food/fAEF/flavouring/docs/ guidance_on_flavouring_substances_with_modifying_properties.pdf

Flamme, E., \& Bom, D. C. (2011). U.S. Patent No. WO 2011/067313, A1. Washington, DC: Patent Cooperation Treaty.

Freitas, M. L. F., Dutra, M. B. L., \& Bolini, H. M. A. (2014). Development of pitanga nectar with different sweeteners by sensory analysis: Ideal pulp dilution, ideal sweetness, and sweetness equivalence. Food Science and Technology, v. 34, n. 1, p. 174-180. http://dx.doi. org/10.1590/S0101-20612014005000008.

Fujiwara, S., Imada, T., Nakagita, T., Okada, S., Nammoku, T., Abe, K., \& Misaka, T. (2012). Sweeteners interacting with the transmembrane domain of the human sweet-taste receptor induce sweet-taste synergism in binary mixtures. Food Chemistry, 130(3), 561-568. http://dx.doi.org/10.1016/j.foodchem.2011.07.073.

Gardner, C., Wylie-Rosett, J., Gidding, S. S., Steffen, L. M., Johnson, R. K., Reader, D., \& Lichtenstein, A. H. (2012). Nonnutritive Sweeteners: current use and health perspectives. Diabetes Care, 35(8), 1798-1808. http://dx.doi.org/10.2337/dc12-9002. PMid:22778165.

Gelski, J. (2016). Sugar reduction meets clean label in soft drinks. Food Business News, Kansas City. Consumer Trends. Retrieved from http://www. foodbusinessnews.net/articles/news_home/Consumer_Trends/2016/05/ Sugar_reduction_meets_clean_la.aspx?ID=\%7B44524EB7-408B4040-8351-C74E10E92F19\%7D\&cck=1

Gibbs, B. F., Alli, I., \& Mulligan, C. (1996). Sweet and taste-modifying proteins: a review. Nutrition Research, 16(9), 1619-1630. http:// dx.doi.org/10.1016/0271-5317(96)00175-3.

Gray, N. (2014). Sweet taste modulator may help provide 'true' sugar taste with zero calories: Senomyx. Breaking news on food and beverage development - North America. Crawley: William Reed Business Media Ltd. Retrieved from http://www.foodnavigator-usa.com/ content/view/print/568133

Grenby, T. H. (1991). Intense sweeteners for the food industry: an overview. Trends in Food Science \& Technology, 2, 2-6. http://dx.doi. org/10.1016/0924-2244(91)90598-D.

Hofmann, T. (2005). Taste-active Maillard reaction products - The "tasty" world of nonvolatile Maillard reaction products (Vol. 1043, pp. 20-29). New York: New York Academy of Sciences.

Jyotaki, M., Shigemura, N., \& Ninomiya, Y. (2010). Modulation of sweet taste sensitivity by orexigenic and anorexigenic factors. Endocrine Journal, 57(6), 467-475. http://dx.doi.org/10.1507/endocrj.K10E095. PMid:20431269.

Kant, R. (2005). Sweet proteins - potential replacement for artificial low calorie sweeteners. Nutrition Journal, 4, 5. http://dx.doi. org/10.1186/1475-2891-4-5. PMid:15703077.

Khattab, S. N., Massoud, M. I., Abd El-Razek, A. M., \& El-Faham, A. (2017). Physico-chemical and sensory characteristics of steviolbioside synthesized from stevioside and its application in fruit drinks and food. Journal of Food Science and Technology, 54(1), 185-195. http:// dx.doi.org/10.1007/s13197-016-2450-2. PMid:28242916.

Kim, N., \& Kinghorn, D. A. (2002). Highly sweet compounds of plant origin. Archives of Pharmacal Research, 25(6), 725-746. http://dx.doi. org/10.1007/BF02976987. PMid:12510821.

Klug, C., \& Lipinski, G. R. (2011). Acesulfame potassium. In L. O. Nabors (Ed.), Alternative sweeteners (pp. 20-25). Boca Raton: CRC Press. http://dx.doi.org/10.1201/b11242-4.

Koizumi, A., Tsuchiya, A., Nakajima, K., Ito, K., Terada, T., ShimizuIbuka, A., Briand, L., Asakura, T., Misaka, T., \& Abe, K. (2011). Human sweet taste receptor mediates acid-induced sweetness of miraculin. Proceedings of the National Academy of Sciences of the
United States of America, 108(40), 16819-16824. http://dx.doi. org/10.1073/pnas.1016644108. PMid:21949380.

Kroger, M., Meister, K., \& Kava, R. (2006). Low-calorie sweeteners and other sugar substitutes: a review of the safety issues. Comprehensive Reviews in Food Science and Food Safety, 5(2), 35-47. http://dx.doi. org/10.1111/j.1541-4337.2006.tb00081.x.

Kumari, A., Choudhary, S., Arora, S., \& Sharma, V. (2016). Stability of aspartame and neotame in pasteurized and in-bottle sterilized flavoured milk. Food Chemistry, 196, 533-538. http://dx.doi. org/10.1016/j.foodchem.2015.09.082. PMid:26593524.

Kurihara, Y., \& Nirasawa, S. (1994). Sweet, antisweet and sweetnessinducing substances. Trends in Food Science \& Technology, 5(2), 37-42. http://dx.doi.org/10.1016/0924-2244(94)90069-8.

Li, X., Bachmanov, A. A., Maehashi, K., Li, W., Lim, R., Brand, J. G., Beauchamp, G. K., Reed, D. R., Thai, C., \& Floriano, W. B. (2011). Sweet taste receptor gene variation and aspartame taste in primates and other species. Chemical Senses, 36(5), 453-475. http://dx.doi. org/10.1093/chemse/bjq145. PMid:21414996.

Meyers, B., \& Brewer, M. S. (2008). Sweet taste in men: a review. Journal of Food Science, 73(6), R81-R90. http://dx.doi.org/10.1111/j.17503841.2008.00832.x. PMid:19241531.

Nabors, L. O., editor (2011). Alternative sweeteners: an overview. In L. O'Brien-Nabors. Alternative sweeteners (pp. 1-9). Boca Raton: CRC Press.

Nakajima, K., Asakura, T., Maruyama, J., Morita, Y., Oike, H., ShimizuIbuka, A., Misaka, T., Sorimachi, H., Arai, S., Kitamoto, K., \& Abe, K. (2006). Extracellular production of neoculin, a sweet-tasting heterodimeric protein with taste-modifying activity, by Aspergillus oryzae. Applied and Environmental Microbiology, 72(5), 3716-3723. http://dx.doi.org/10.1128/AEM.72.5.3716-3723.2006. PMid:16672522.

Nelson, G., Hoon, M. A., Chandrashekar, J., Zhang, Y., Ryba, N. J., \& Zuker, C. S. (2001). Mammalian sweet taste receptors. Cell, 106(3), 381-390. http://dx.doi.org/10.1016/S0092-8674(01)004512. PMid:11509186.

Ottinger, H., \& Hofmann, T. (2003). Identification of the taste enhancer alapyridaine in beef broth and evaluation of its sensory impact by taste reconstitution experiments. Journal of Agricultural and Food Chemistry, 51(23), 6791-6796. http://dx.doi.org/10.1021/jf034788r. PMid:14582976.

Ottinger, H., Soldo, T., \& Hofmann, T. (2003). Discovery and structure determination of a novel Maillard-derived sweetness enhancer by application of the comparative taste dilution analysis (cTDA). Journal of Agricultural and Food Chemistry, 51(4), 1035-1041. http://dx.doi. org/10.1021/jf020977i. PMid:12568569.

Priya, K., Gupta, V. R. M., \& Srikanth, K. (2011). Natural sweeteners: a complete review. Journal of Pharmacy Research, 4(7), 2034-2039.

Raben, A., Vasilaras, T. H., Møller, A. C., \& Astrup, A. (2002). Sucrose compared with artificial sweeteners: different effects on ad libitum food intake and body weight after $10 \mathrm{wk}$ of supplementation in overweight subjects. The American Journal of Clinical Nutrition, 76(4), 721-729. http://dx.doi.org/10.1093/ajcn/76.4.721. PMid:12324283.

Ribeiro, G., \& Santos, O. (2013). Recompensa alimentar: mecanismos envolvidos e implicações para a obesidade. Revista Portuguesa de Endocrinologia, Diabetes \& Metabolismo, 8(2), 82-88. https://doi. org/10.1016/j.rpedm.2013.09.001.

Riera, C. E., Vogel, H., Simon, S.A., \& le Coutre, J. (2007). Artificial sweeteners and salts producing a metallic taste sensation activate TRPV1 receptors. The American Journal of Physiology - Regulatory, Integrative and Comparative Physiology, 293(2), 626-634. http:// dx.doi.org/10.1152/ajpregu.00286.2007. PMID: 17567713. 
Rodrigues, J. F., Andrade, R. D. S., Bastos, S. C., Coelho, S. B., \& Pinheiro, A. C. M. (2016). Miracle fruit: an alternative sugar substitute in sour beverages. Appetite, 107, 645-653. http://dx.doi.org/10.1016/j. appet.2016.09.014. PMid:27637500.

Sardesai, V. M., \& Waldshan, T. H. (1991). Natural and synthetic intense sweeteners. The Journal of Nutritional Biochemistry, 2(5), 236-244. http://dx.doi.org/10.1016/0955-2863(91)90081-F.

Schiffmann, S. S., \& Gatlin, C. A. (1993). Sweeteners: state of knowledge review. Neuroscience and Biobehavioral Reviews, 17(3), 313-345. http://dx.doi.org/10.1016/S0149-7634(05)80015-6. PMid:8272285.

Scott-Thomas, C. (2014). Senomyx and firmenich to partner on natural sweetness enhancers. Crawley: William Reed Business Media Ltd. Retrieved from http://www.foodnavigator-usa.com/content/view/ print $/ 345603$

Servant, G., Tachdjian, C., Li, X., \& Karanewsky, D. S. (2011). The sweet taste of true synergy: positive allosteric modulation of the human sweet taste receptor. Trends in Pharmacological Sciences, 32(11), 631636. http://dx.doi.org/10.1016/j.tips.2011.06.007. PMid:21807420.

Servant, G., Tachdjian, C., Tang, X. Q., Werner, S., Zhang, F., Li, X., Kamdar, P., Petrovic, G., Ditschun, T., Java, A., Brust, P., Brune, N., DuBois, G. E., Zoller, M., \& Karanewsky, D. S. (2010). Positive allosteric modulators of the human sweet taste receptor enhance sweet taste. Proceedings of the National Academy of Sciences of the United States of America, 107(10), 4746-4751. http://dx.doi.org/10.1073/ pnas.0911670107. PMid:20173092.

Sigoillot, M., Brockhoff, A., Meyerhof, W., \& Briand, L. (2012). Sweettaste-suppressing compounds: current knowledge and perspectives of application. Applied Microbiology and Biotechnology, 96(3), 619630. http://dx.doi.org/10.1007/s00253-012-4387-3. PMid:22983596.

Soldo, T., Blank, I., \& Hofmann, T. (2003). (+)-(S)-Alapyridaine-A general taste enhancer? Chemical Senses, 28(5), 371-379. http:// dx.doi.org/10.1093/chemse/28.5.371. PMid:12826533.

Soldo, T., Frank, O., Ottinger, H., \& Hofmann, T. (2004). Systematic studies of structure and physiological activity of alapyridaine. A novel food-born taste enhancer. Molecular Nutrition \& Food Research, 48(4), 270-281. http://dx.doi.org/10.1002/mnfr.200400025. PMid:15497178.

Stoger, E. (2012). Plant bioreactors - the taste of sweet success. Biotechnology Journal, 7(4), 475-476. http://dx.doi.org/10.1002/ biot.201100472. PMid:22253253.
Strapasson, G. C., Lopez, A. C. M., Basso, T., Santos, D. F., Mulinari, R. A., Wille, G. M. F. C., \& Barreira, S. W. (2011). Percepção de sabor: uma revisão. Visão Acadêmica, 12(1), 65-73.

Sun, H., Cui, M. L., Ma, B., \& Ezura, H. (2006). Functional expression of the taste-modifying protein miraculin, in transgenic lettuce. Federation of European Biochemical Societies, 580(2), 620-626. http:// dx.doi.org/10.1016/j.febslet.2005.12.080. PMid:16406368.

Swithers, S. E., Martin, A. A., \& Davidson, T. L. (2010). High-intensity sweeteners and energy balance. Physiology \& Behavior, 100(1), 55-62. http://dx.doi.org/10.1016/j.physbeh.2009.12.021. PMid:20060008.

Tandel, K. R. (2011). Sugar substitutes: Health controversy over perceived benefits. Journal of Pharmacology \& Pharmacotherapeutics, 2(4), 236243. http://dx.doi.org/10.4103/0976-500X.85936. PMid:22025850.

U.S. Food and Drug Administration - FDA. (2015). Food Additives \& Ingredients. Additional Information about High-Intensity Sweeteners Permitted for use in Food in the United States. Retrieved from https://www.fda.gov/food/ingredientspackaginglabeling/ foodadditivesingredients/ucm $397725 . \mathrm{htm}$

Watson, E. (2014). Senomyx: new sucrose enhancer could help firms slash sugar by 50 percent. Crawley: William Reed Business Media Ltd. Retrieved from http://www.foodnavigator-usa.com/content/ view/print/391892

Wessjohann, L., Backes, M., Ley, J. P., Paetz, S., \& Reichelt, K. (2010). U.S. No. 2010/0292175 A1. Washington, DC: U.S. Patent and Trademark Office.

Yoshida, R., Ohkuri, T., Jyotaki, M., Yasuo, T., Horio, N., Yasumatsu, K., Sanematsu, K., Shigemura, N., Yamamoto, T., Margolskee, R. F., \& Ninomiya, Y. (2010). Endocannabinoids selectively enhance sweet taste. Proceedings of the National Academy of Sciences of the United States of America, 107(2), 935-939. http://dx.doi.org/10.1073/ pnas.0912048107. PMid:20080779.

Zhang, F., Klebansky, B., Fine, R. M., Liu, H., Xu, H., Servant, G., Zoller, M., Tachdjian, C., \& Li, X. (2010). Molecular mechanism of the sweet taste enhancer. Proceedings of the National Academy of Sciences of the United States of America, 107(10), 4752-4757. http:// dx.doi.org/10.1073/pnas.0911660107. PMid:20173095.

Zhao, G. Q., Zhang, Y., Hoon, M. A., Chandrashekar, J., Erlenbach, I., Ryba, N. J., \& Zuker, C. S. (2003). The receptors for mammalian sweet and umami taste. Cell, 115(3), 255-266. http://dx.doi.org/10.1016/ S0092-8674(03)00844-4. PMid:14636554. 